資料來源：本雜誌專訪、蔡豊珍老師。

資料編輯：本雜誌。

資料校稿：蔡豊珍老師。

現職：e 之堡科學創意中心主任。

學歷：1.國立台北工專（台北科技大學）畢。

2.國立高雄師範大學科技教育研究所。

經歷：1.中船公司工程師、訓練中心代主任。

2. 指導學生參加國際機器人競賽累計獲金牌五面、銀牌

三面、銅牌二面。

3. 高雄市政府教育局、中國生產力中心講師。

研究領域：機器人創意教學、機電整合、金工、品質管理。

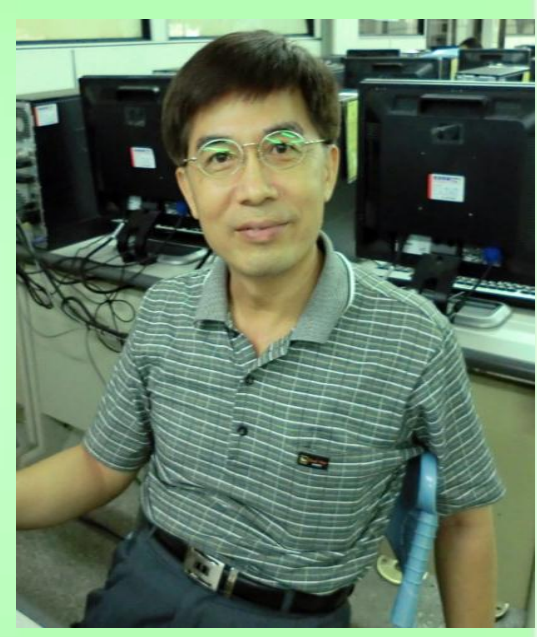

此專欄專訪機器人常勝軍蔡豊珍老師, 介紹蔡老師指導學生參加各種競賽之經驗, 希望提 供有意带隊之老師與有意參加競賽之學生作為準備比賽之參考。

\title{
2011-2012 戰績
}

2011 屏東科技大學第六屆全國工業機器人競賽獲 A 組第一名及技術獎。

2011 FLL(FIRST LEGO League)台灣區選拔獲第一、二名。代表國家參加美國聖路易世界盃 機器人大賽榮獲策略與創新第二名、荷蘭台夫特 FLL OEC 歐洲公開賽機器人表現世界 冠軍。

2011 WRO 國際奥林匹克機器人大賽校際盃小學組第一、二、三名, 高中組第二名。南區初 賽小學組第一、三名，國中組第一名。代表國家參加阿布達比國際大賽。

2011 IRHOCS 國際機器人實作競賽機器人保齡球組第一、二名。

2012 屏東科技大學第七屆全國工業機器人競賽獲 $\mathrm{A}$ 組第一、二名及擬真獎。

2012 FLL(FIRST LEGO League)台灣區選拔獲第一名, 代表國家參加六月德國歐洲冠軍公開 賽。

2012 教育部技專校院國際科技藝能大賽(2012 國際智慧型機器人競賽)無動力雙足機器人組 第二、三名。

2012 WRO 國際奥林匹克機器人大賽校際盃小學組第一名, 國中組第一、二名, 高中組第二 名。南區初賽國小組第二名, 全國決賽國小組第一名。代表國家參加馬來西亞吉隆坡 國際大賽。

2012 TYRSC 台灣青少年機器人科學創意競賽機器人保齡球賽第一、三名, 機器人相撲羽量 級最佳創意獎。 